\title{
Diagnoza potencjału innowacyjności i konkurencyjności przedsiębiorstw
}

https://doi.org/10.33141/po.2005.05.08

\section{Janusz Pawłowski}

Przegląd Organizacji, Nr 5 (784), 2005, ss. 28-30 www.przegladorganizacji.pl Towarzystwo Naukowe Organizacji i Kierownictwa (TNOiK)

\section{Cel badań}

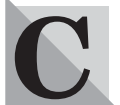

elem pracy jest zdefiniowanie metody oceny potencjału innowacyjności i konkurencyjności przedsiębiorstwa oraz jej weryfikację na wybranym przypadku prywatyzacji bezpośredniej.

\section{Koncepcja struktury potencjału zasobowego}

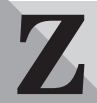

godnie z podejściem zasobowym o „[...] sukcesie przedsiębiorstwa decyduje jego potencjał strategiczny w postaci odpowiednio dobranych i konkurencyjnych zasobów oraz zdolność przedsiębiorstwa do ich innowacyjnego i efektywnego wykorzystania. Według tej koncepcji, sukces na rynku odnoszą te przedsiębiorstwa, które mają większe zdolności tworzenia swoich kluczowych umiejętności i ich wykorzystania w walce konkurencyjnej" [2, s. 162].

W latach 90. ub. wieku zwrócono szczególną uwagę na rolę i znaczenie zasobów opartych na wiedzy. „Wiedza i informacja, ich jakość i aktualność, stają się dla przedsiębiorstwa istotnymi czynnikami konkurencyjności” [3, s. 68]. Według C. Prahalada i G. Hamela [17, s. 8] źródłem przewagi konkurencyjnej są kluczowe kompetencje, określane jako kombinacja indywidualnych technologii i umiejętności produkcyjnych, które tworzą możliwości rozwoju podstawowych linii produktów przedsiębiorstwa. Kompetencje są kluczowe, jeżeli wnoszą bardzo duży wkład w wartość postrzeganą przez klienta, są unikatowe i pozwalaja na rozszerzanie oferty produktowej i rynku. G. Stalk, P. Evans i L.E. Shulman [9, s. 62] definiują pojęcie „wyróżniające zdolności” jako pewien wzór zachowań; mechanizm, dzięki któremu kluczowe kompetencje są wprowadzane w życie.

M. Szymura-Tyc formułuje własne interpretacje pojęć zdolności, umiejętności i kompetencji. „Zdolność przedsiębiorstwa są to powtarzające się wzorce działania w korzystaniu z zasobów, w celu kreowania, produkowania i/lub oferowania produktów na rynku". Uważa się je za szczególnie ważną kategorię zasobów, ponieważ warunkują one wykorzystanie zasobów materialnych. Natomiast „umiejętności są ujmowane jako specyficzna forma zdolności, odnosząca się do konkretnej sytuacji lub związana z wykorzystaniem konkretnego zasobu”. Z kolei „kompetencje są definiowane jako zdolność do skoordynowanego zaangażowania zasobów materialnych i niematerialnych, w tym zdolności, umiejętności i wiedzy, dla osiągnięcia celów organizacji” [10, s. 8]. Zdolność i kompetencje odnoszą się do organizacji jako całości; umiejętności dotyczą raczej jednostek zasobów.

\section{Założenia metody diagnozy potencjału innowacyjności i konkurencyjności}

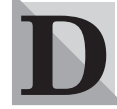

o oceny innowacyjności i konkurencyjności przedsięwzięć gospodarczych proponuje się stosować metodę nazwaną diagnozą potencjału innowacyjności i konkurencyjności. Celem tej metody jest identyfikacja i ocena sprawczych czynników wzrostu innowacyjności i konkurencyjności, które tkwią w szeroko rozumianych zasobach analizowanego przedsiębiorstwa. Zakres diagnozy obejmuje:

- zdefiniowanie obszarów głównych pól tematycznych zasobów oraz pakietu (listy) głównych czynników innowacyjności i konkurencyjności charakterystycznych dla badanego przypadku,

- analizę obszarów, pól tematycznych i sił kształtujących główne czynniki innowacyjności i konkurencyjności, wraz z oceną jakościowa,

- wyjaśnianie istoty i wagi oddziaływania czynników na innowacyjność i/lub konkurencyjność,

- jakościową i wartościową ocenę poszczególnych czynników i całego pakietu.

Na potrzeby identyfikacji głównych czynników innowacyjności i konkurencyjności, szeroko rozumiane zasoby przedsięwzięcia gospodarczego podzielono na trzy obszary rodzajowe oraz 12 pól tematycznych, a mianowicie:

- obszar kapitału intelektualnego: inteligencja firmy, potencjał intelektualny pracowników, partycypacja pracownicza, struktura własności, potencjał intelektualny i skuteczność menedżerów, potencjał kapitału strukturalnego.

- obszar kapitału rzeczowego: produkt, potencjał techniczno-technologiczny, logistyka, sieć dystrybucji.

- obszar kapitału finansowego: struktura majątku i kapitału, przewidywane przepływy pieniężne, możliwości pozyskania kapitału.

Proponowany podział zasobów przedsiębiorstwa nie jest zbiorem zamkniętym i w każdym przypadku analizy powinien być weryfikowany w zależności od wielkości przedsięwzięcia, jego specyfiki, branży, przedmiotu działalności, segmentu i zakresu rynku, do którego adresowany jest produkt.

\section{Główne czynniki innowacyjności i konkurencyjności}

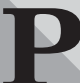

ostulowaną listę głównych czynników innowacyjności i konkurencyjności przedsiębiorstwa wraz z definicją czynnika i wskazaniem pól tematycznych, które z istotną siłą ksztaltują dany czynnik, sformułowano następująco. 
- Zdolność inwencji, kreowania i podejmowania innowacji - oznacza dokonanie odkrywczej inwencji, przekształcenie jej w realistyczny projekt i dokonanie zastosowania tego projektu w działalności przedsiębiorstwa w celu utrzymania i/lub podniesienia jego konkurencyjności.

Podstawowe pola kształtujace ten czynnik to: potencjał intelektualny i skuteczność menedżerów, inteligencja firmy, potencjał intelektualny pracowników. - Umiejętność chłonności innowacji - oznacza proinwestycyjną postawę pracowników, menedżerów i struktur przedsiębiorstwa (chłonność wewnętrzna) oraz akceptację innowacji przez indywidualnych konsumentów, nabywców (chłonność rynkowa).

Pola kształtujące czynnik: partycypacja pracownicza, potencjał intelektualny i skuteczność menedżerów, kapitał strukturalny, logistyka dystrybucji.

- Zdolności strukturalne wzmocnienia pozycji konkurencyjnej to potencjalne możliwości powiększenia udziału w rynku, tkwiące w posiadanej infrastrukturze technicznej i organizacyjnej.

Główne pola tematyczne to: potencjał kapitału strukturalnego, logistyka dystrybucji.

- Kompetencje rozwoju innowacyjności produktowej to możliwości wzbogacenia cech indywidualnych produktu oraz asortymentu produktu na bazie posiadanego potencjału techniczno-technologicznego i finansowego.

Pola kształtujące czynnik: potencjał produktu, potencjał techniczno-technologiczny, inteligencja firmy. - Zdolności innowacyjne potencjału techniczno-technologicznego, oznaczają stopień atrakcyjności i innowacyjności posiadanej techniki i technologii. Główne pola kształtujące ten czynnik to: potencjał techniczno-technologiczny, potencjał finansowy, inteligencja firmy.

- Umiejętność wzmocnienia konkurencyjności kosztowej, rozumiana jest jako rezerwy kosztowe tkwiące w procesach zarządzania działaniami logistycznymi i produkcyjnymi.

Pola kształtujące czynnik to: logistyka zaopatrzenia logistyka dystrybucji, potencjał produktu, potencjał techniczno-technologiczny.

- Zdolność finansowania działań innowacyjnych i działań wspierających konkurencyjność rynkowa, to aktualne nadwyżki kapitałowe oraz realne możliwości pozyskania źródeł finansowania wewnętrznego i zewnętrznego.

Podstawowe pola tematyczne to: struktura majątku i kapitału, przewidywane przepływy pieniężne, możliwości pozyskania kapitału.

Mając zidentyfikowane pola tematyczne potencjału zasobowego oraz ich związek i siłę oddziaływania na określony czynnik innowacyjności, możemy przystąpić do oceny jakościowej i wartościowej poszczególnych czynników.

\section{Analiza przypadku}

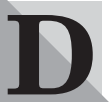

iagnozie potencjału innowacyjności i konkurencyjności poddano podmioty gospodarcze, jakie hipotetycznie powstałyby w wyniku prywatyzacji przedsiębiorstwa państwowego o umownej nazwie ABBA w formach: leasingu prywatyzacyjnego, wniesienia przedsiębiorstwa do spółki z udziałem skarbu państwa oraz sprzedaży przedsiębiorstwa w dwóch wariantach ceny sprzedaży [6, s. 173]. Za- stosowanie metody diagnozy potencjału ma na celu udzielenie odpowiedzi na pytanie, która z form prywatyzacji generuje dodatkowy potencjał innowacyjności i konkurencyjności, innymi słowy, jakie podmioty powstałe w wyniku przekształcenia przedsiębiorstwa miałyby największe szanse rozwoju w konkurencyjnym otoczeniu.

Potencjał zasobowy badanego przedsiębiorstwa obejmuje dwa poziomy:

- poziom wyjściowy - odnosi się do stanu zasobów przedsiębiorstwa przed przekształceniem i jest identyczny dla wszystkich analizowanych form;

- poziom zmiany - odnosi się do możliwości zmiany istniejaccego potencjału w wyniku procesu prywatyzacji, przy czym skala tej zmiany jest zróżnicowana i zależy od formy prywatyzacji.

Poziom wyjściowy oceniono na podstawie szerokich analiz zasobów przedsiębiorstwa i otoczenia konkurencyjnego wymaganych w dokumentacji prywatyzacyjnej oraz swobodnych, niesformalizowanych wywiadów z kadra kierowniczą i samorzadem przedsiębiorstwa. Punktem odniesienia oceny czynników był średni poziom ukształtowany w grupie trzech głównych konkurentów działajacych w branży analizowanego przedsiębiorstwa.

Do oceny poziomu zmiany potencjału innowacyjności i konkurencyjności podmiotów po przekształceniu wykorzystano: diagnozę motywów i celów uczestników prywatyzacji [6], wyniki kalkulacji kosztu pozyskania kapitału wykonanej dla analizowanych wariantów przekształcenia [6], wyniki badań Instytutu Studiów Politycznych PAN [4, 5], inne wyniki badań przeprowadzanych w Polsce $[1,8]$.

Kształtowanie się potencjału rzeczowego na „poziomie zmiany" jest w znacznej mierze skutkiem inicjowania i efektywnego wykorzystania potencjału intelektualnego i finansowego. Stąd ocena możliwości rozwoju innowacyjności produktowej, potencjału techniczno-technologicznego czy też strukturalnego wzmocnienia pozycji konkurencyjnej jest silnie skorelowana z możliwościami kapitału ludzkiego, strukturalnego i możliwościami finansowymi w analizowanych opcjach inwestowania w mienie prywatyzowanego przedsiębiorstwa.

\section{Ocena głównych czynników innowacyjności i konkurencyjności}

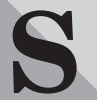

posób oceny głównych czynników innowacyjności i konkurencyjności ma wymiar jakościowy i ilościowy (wartościowy). W pierwszej części diagnozy, po akceptacji struktury zasobów, przeprowadza się analizę pól tematycznych w aspekcie ich związków przyczynowo-skutkowych oraz siły oddziaływania na wskazane czynniki innowacyjności i konkurencyjności, a następnie na podstawie takiej analizy dokonuje się oceny ilościowej.

Pierwszy krok w ocenie ilościowej (zob. tabela) polega na przypisaniu poszczególnym czynnikom określonych wag, które odzwierciedlają siłę oddziaływania tych czynników na innowacyjność i konkurencyjność firmy, powstałej w wyniku przekształcenia własnościowego. Suma wag wynosi 1 . Została ona rozdzielona między 7 głównych czynników, według założenia zdecydowanie preferującego czynnik finansowy $(0,3)$ oraz zdolność inwencji, kreowania i podejmowania innowacji $(0,2)$. Pozostałym czynnikom przydzielono 
Tab. Ocena potencjału innowacyjności i konkurencyjności firm po prywatyzacji

\begin{tabular}{|c|c|c|c|c|c|c|c|c|c|c|}
\hline \multirow[b]{2}{*}{ Czynniki* } & \multirow[b]{2}{*}{ Waga } & \multirow{2}{*}{\begin{tabular}{|c|}
$\begin{array}{c}\text { Przedsię- } \\
\text { biorstwo }\end{array}$ \\
$\begin{array}{c}\text { poziom } \\
\text { wyjściowy }\end{array}$ \\
\end{tabular}} & \multicolumn{2}{|c|}{ Spółka leasingowa } & \multicolumn{2}{|c|}{$\begin{array}{l}\text { Spółka z udziałem } \\
\text { skarbu państwa }\end{array}$} & \multicolumn{2}{|c|}{$\begin{array}{c}\text { Sprzedaż } \\
\text { (wariant 1) }\end{array}$} & \multicolumn{2}{|c|}{$\begin{array}{c}\text { Sprzedaż } \\
\text { (wariant 2) }\end{array}$} \\
\hline & & & $\begin{array}{l}\text { poziom } \\
\text { zmiany }\end{array}$ & $\begin{array}{c}\text { ważona } \\
\text { ocena } \\
\text { czynnika }\end{array}$ & $\begin{array}{l}\text { poziom } \\
\text { zmiany }\end{array}$ & $\begin{array}{c}\text { ważona } \\
\text { ocena } \\
\text { czynnika }\end{array}$ & $\begin{array}{l}\text { poziom } \\
\text { zmiany }\end{array}$ & $\begin{array}{c}\text { ważona } \\
\text { ocena } \\
\text { czynnika }\end{array}$ & $\begin{array}{l}\text { poziom } \\
\text { zmiany }\end{array}$ & $\begin{array}{c}\text { ważona } \\
\text { ocena } \\
\text { czynnika }\end{array}$ \\
\hline 1. & 0,2 & 4 & 4 & 0,80 & 2 & 0,60 & 4 & 0,80 & 3 & 0,70 \\
\hline 2. & 0,1 & 3 & 4 & 0,35 & 3 & 0,30 & 4 & 0,35 & 3 & 0,30 \\
\hline 3. & 0,1 & 2 & 4 & 0,30 & 4 & 0,30 & 4 & 0,30 & 3 & 0,25 \\
\hline 4. & 0,1 & 3 & 3 & 0,30 & 4 & 0,35 & 4 & 0,35 & 3 & 0,30 \\
\hline 5. & 0,1 & 1 & 2 & 0,15 & 4 & 0,25 & 3 & 0,20 & 2 & 0,15 \\
\hline 6. & 0,1 & 4 & 2 & 0,30 & 3 & 0,35 & 3 & 0,35 & 2 & 0,30 \\
\hline 7. & 0,3 & 2 & 3 & 0,75 & 5 & 1,05 & 2 & 0,60 & 1 & 0,45 \\
\hline \begin{tabular}{|c|} 
Suma \\
wartości \\
ważonych
\end{tabular} & & & \multicolumn{2}{|c|}{2,95} & \multicolumn{2}{|c|}{3,20} & \multicolumn{2}{|c|}{2,95} & \multicolumn{2}{|c|}{2,45} \\
\hline
\end{tabular}

* numeracja zgodna z podaną wyżej listą czynników

Źródło: opracowanie własne.

równe wagi $(0,1)$, co w rezultacie prowadzi do w miarę równorzędnego traktowania sił oddziaływania wydzielonych obszarów zasobów.

Do oceny poziomu wyjściowego i poziomu zmiany czynnika przyjęto skalę od zera do pięciu, przy czym: 0 - oznacza brak potencjału; 1-2 - niski poziom; 3 przeciętny poziom; 4-5 - wysoki poziom.

Ocena poszczególnych czynników jest średnią arytmetyczną ocen poziomu wyjściowego i poziomu zmiany, natomiast iloczyn średniej wartości czynnika i wagi tego czynnika określa ważoną wartość czynnika. Suma wartości ważonych jest wskaźnikiem innowacyjności i konkurencyjności nowej firmy. Ponieważ poziom potencjału wyjściowego oszacowano w odniesieniu do głównych konkurentów, a poziom zmiany proporcjonalnie do skali potencjału wyjściowego, można przyjąć, że jest to wskaźnik właściwy do analiz porównawczych w ramach badanych wariantów przekształcenia, a także podmiotów działających w sektorze (branży) analizowanego przedsiębiorstwa.

\section{Podsumowanie}

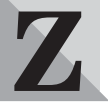

przeprowadzonej diagnozy głównych czynników innowacyjności i konkurencyjności podmiotów, powstałych w wyniku różnych form i wariantów przejęcia mienia przedsiębiorstwa ABBA wynika, że zdecydowanie najwyższą ocenę uzyskuje spółka z udziałem skarbu państwa. Natomiast najniższą osiąga podmiot, który przejmuje przedsiębiorstwo $\mathrm{w}$ formie jego sprzedaży przez skarb państwa, przy założeniu, że cena sprzedaży byłaby wyższa o ponad $20 \%$ od wartości przedsiębiorstwa wynegocjowanej w przypadku leasingu prywatyzacyjnego. Oceny spółki leasingowej i podmiotu kupujacego przedsiębiorstwo ABBA po cenie równej wartości przedsiębiorstwa ustalonej w leasingu prywatyzacyjnym, kształtują się na porównywalnym poziomie.

Wykonana diagnoza może być podstawą do następujących wniosków.

- Jakościowa i ilościowa ocena głównych czynników innowacyjności i konkurencyjności powinna być wspomagana szerokimi analizami zasobów przed- siębiorstwa, zewnętrznymi badaniami efektywności działania spółek powstałych w wyniku prywatyzacji, a także analizą branży (sektora) lub wzorcowej firmy w branży.

- Syntetyczny wskaźnik innowacyjności i konkurencyjności firmy może być stosowany jako jedno z kryteriów wyboru formy prywatyzacji droga bezpośrednią.

Można sądzić, że przedstawiony przykład aplikacji metody pozwala też na postawienie hipotezy o możliwościach jej szerszego zastosowania w analizach porównawczych podmiotów gospodarczych czy w celach klasyfikowania i selekcji projektów inwestycyjnych.

dr inż. Janusz Pawtowski

Katedra Ekonomiki Przemysłu i Rynku Kapitałowego w Uniwersytecie Łódzkim

\section{BIBLIOGRAFIA}

[1] BAŁTOWSKI M., Przedsiębiorstwa sprywatyzowane $w$ gospodarce polskiej, PWN, Warszawa 2002.

[2] GIERSZEWSKA G., ROMANOWSKA M., Analiza strategiczna przedsiębiorstwa, PWE, Warszawa 2002.

[3] GRUDZEWSKI W.M., HEJDUK I.K., Zarzadzanie wiedza w przedsiębiorstwie, Difin, Warszawa 2004.

[4] JAROSZ M., Prywatyzacja bezpośrednia, PAN-ISP, Warszawa 1998.

[5] JAROSZ M., Pułapki prywatyzacji, INP PAN, Warszawa 2003.

[6] PAWŁOWSKI J., Metodyka oceny efektywności finansowej przedsięwzięć gospodarczych, Wyd. Uniwersytetu Łódzkiego, Łódź 2004.

[7] PRAHALAD C.K., HAMEL G., The Core Competence of the Corporation, „Harvard Business Review”, maj-czerwiec 1990.

[8] RUDOLF S., Partycypacja pracownicza, Wyd. Uniwersytetu Łódzkiego, Łódź 2001.

[9] STALK G., EVANS P., SHULMAN L.E., Competing on Capabilities: The New Rules of Corporate Strategy, „Harvard Business Review", marzec-kwiecień 1992.

[10] SZYMURA-TYC M., Zasoby oparte na wiedzy w procesie budowy przewagi konkurencyjnej przedsiębiorstw, „Przegląd Organizacji”, nr 3/2002. 